\title{
Short-term and long-term influences on the immigration of postlarval banana prawns Penaeus merguiensis, into a mangrove estuary of the Gulf of Carpentaria, Australia
}

\author{
D. J. Staples \& D. J. Vance \\ Division of Fisheries Research, CSIRO Marine Laboratories, P.O.Box 120, Cleveland, Qld 4163, Australia
}

\begin{abstract}
Postlarval Penaeus merguiensis de Man were sampled regularly at the mouth of the Norman River estuary in the south-eastern Gulf of Carpentaria, Australia, from 1975 to 1979 . A grid of stations up to $10 \mathrm{~km}$ offshore from the estuary mouth was also occupied over a $24 \mathrm{~h}$ period during November 1978. In these offshore stations, postlarvae migrated vertically in the water column in response to changes in tidal height, rising to near the surface just before low tide. Postlarvae entered the estuary throughout the flood tide with a peak in abundance occurring at the time of maximum current, regardless of time of day or night. During the monsoonal wet season (Dec-Mar), when estuary salinities were lower, postlarvae occurred deeper in the water column. Over the $4 \mathrm{yr}$ of sampling, immigration on a day-to-day basis was extremely variable but a consistent spring-neap tidal cycle could be demonstrated. More postlarvae immigrated during the spring-tide period than during the neaps, although the pattern was complicated by a larger peak associated with every second spring tide $(27.32 \mathrm{~d})$. Although difficult to separate from tidal phase changes, lunar changes per se appeared to be less important than the relation between tidal phase changes and timing of moonset and moonrise. Immigration was restricted to the warmer months between October and April each year, with a large pulse of recruits occurring usually in spring (Oct-Nov) and a less consistent pulse occurring in autumn (Mar-May). Inter-annual variations were also large and it was suggested that these year-to-year differences were related to the amount of rainfall recorded during the previous wet season $(9 \mathrm{mo}$ earlier) and the associated changes in salinity, temperature, nutrients and abundance of adult prawns. Over larger time scales, both size and developmental stage (number rostral spines) were directly related to postlarval abundance. Thus, postlarvae tended to be larger and more well developed during spring and autumn of each year, and were also larger during years of higher immigration rates. Increased growth as well as survival in years following good rainfall and enrichment is suggested.
\end{abstract}

\section{INTRODUCTION}

The large fluctuations in annual yield of many penaeid prawn fisheries are well documented (e.g. American Gulf of Mexico: Rothschild \& Brunenmeister 1984; Pacific Coast of Mexico: Edwards 1978; India: Silas et al. 1984; Iran, Kuwait, Saudi Arabia and Bahrain: Van Zalinge 1984; Australia: Thompson 1955, Somers \& Taylor 1981). The causes of these year-toyear fluctuations, however, remain largely unexplained. Correlations between the annual catch of several species of penaeid prawns and various environmental variables have been described. Factors considered important in these studies included water temperature (Williams 1969, Barrett \& Gillespie 1973, 1975, Hunt et al. 1980), rainfall (Hildebrand \& Gunter 1953,
Gunter \& Edwards 1969, Barrett \& Gillespie 1973, 1975, Ruello 1973, Edwards 1978, Vance et al. in press) and river discharge (Subrahmanyam 1966, Barrett \& Gillespie 1973, 1975, Glaister 1978). More recently, a dependence on the stock density of adult prawns in the previous year has been suggested for Penaeus aztecus in the Gulf of Mexico (Rothschild \& Brunenmeister 1984). Models derived from these types of analyses are useful in short-term forecasting of stock fluctuations, but add little information about how population numbers and biomass are controlled and limited. Only one data point can be collected each year and this point represents the net result of the influence of a wide range of factors, each acting at different stages of the prawn's life cycle.

Most penaeid prawns spawn in the open sea, and 
after a short larval life of 2 to $3 \mathrm{wk}$, postlarvae migrate to inshore and estuarine waters. After several months of rapid growth and development, an offshore migration from these nursery areas occurs and maturation and spawning takes place. For species in which the estuary is an obligatory stage in the life cycle, a convenient measure of the survival of off-shore larval stages and juveniles can be obtained from quantitative sampling of postlarval immigration and juvenile emigration, respectively. In this paper we examine factors affecting the immigration of postlarval Penaeus merguiensis into the Norman River estuary in the southeastern Gulf of Carpentaria. The main data base for this study was collected during a sampling program which monitored postlarval ingress into the estuary regularly from September 1975 to September 1979. Some aspects of the tidal periodicity and seasonality of postlarval abundance during the first year of study have been published (Staples 1980a). In the present analysis we examine the variation of postlarval numbers on time scales ranging from short-term variation throughout a tidal cycle, to year-to-year comparisons.

Reviews by Edwards (1978) and Garcia \& Le Reste (1981) have described the diel, tidal, lunar, and seasonal periodicity in the abundance of postlarvae of several species of penaeid prawns. In general, postlarvae enter the estuaries on flood tides with greater numbers being observed at night. Catches are reported to be higher during the new moon, although a less important peak at full moon has sometimes been recorded. Many species exhibit seasonal cycles of abundance which are commonly interpreted as reflecting differences in seasonal spawning activity. More recently, seasonal changes in the advection of larvae from spawning areas to inshore nursery areas have been described. Rothlisberg et al. (1983) have demonstrated that seasonal changes in the timing of tidal currents relative to the timing of vertical migratory behaviour of penaeid larvae results in a different seasonal pattern of postlarval immigration in different areas of the Gulf of Carpentaria.

Penaeus merguiensis postlarvae have been studied in the Goa estuarine system in India (Goswami \& George 1978), Straits of Malacca in Malaysia (Chong 1979), and Gulf of Carpentaria in Australia (Staples $1979,1980 a)$. Most workers have found that the maximum ingress of postlarvae occurs mainly during the flooding tide at night, but the seasonal peaks of abundance vary markedly among different locations. In the southern Gulf of Carpentaria the main period of immigration over the period 1970-1973 occurred during the spring pre-monsoon months (Oct-Nov), whereas in the north-eastern Gulf, immigration was largely confined to the autumn post-monsoon period (Mar-Apr) (Staples 1979). In 2 adjacent estuaries in
Goa, postlarvae occurred in the pre-monsoon months (Mar-May) in one estuary but did not occur until after the monsoon (Oct-Nov) in the other (Selvakumar et al 1977, Goswami \& George 1978). In the Philippines, $P$. merguiensis immigrated into an estuary studied by Motoh (1981) with a main peak in October-November and another in June-July. In all these localities, the underlying pattern appears to be 2 main periods of spawning and immigration of postlarvae each year but local conditions may modify the pattern so that either one or the other peak becomes dominant. Few data are available to describe how these seasonal patterns differ from year-to-year in any one location and factors affecting the inter-annual variation in the strength of postlarval immigration are also largely unknown. The present study attempts to rectify this deficiency for $P$. merguiensis in the south-eastern Gulf of Carpentaria.

\section{MATERIALS AND METHODS}

Offshore sampling. The vertical migratory behaviour of postlarval Penaeus merguiensis was investigated in late November 1978 at nine stations situated up to $10 \mathrm{~km}$ offshore from the Norman River estuary mouth (Fig. 1a). Three stations situated in the main channel were sampled for 10 min every $2 \mathrm{~h}$ over a $24 \mathrm{~h}$ period. Depth of water in the channel ranged from 3 to $5 \mathrm{~m}$ depending on tide stage, which enabled 3 depth strata (surface, middle, bottom) to be sampled simultaneously using 3 towed $0.5 \mathrm{~m} \times 0.5 \mathrm{~m}$ plankton nets fitted with $1 \mathrm{~mm}$ mesh netting. A flowmeter attached to the mouth of each net allowed the calculation of the volume of water filtered during the tow. At the time of high and low tides, a further 6 stations in the shallow water adjacent to the channel were sampled using the same techniques. Postlarvae of the genus Penaeus were sorted from the samples under a stereoscopic dissecting microscope, and postlarval $P$. merguiensis were identified from rostral and telson characters as described by Staples (1980a). Carapace length of all specimens was measured to the nearest $0.1 \mathrm{~mm}$ using an ocular micrometer.

Estuarine sampling. Planktonic postlarvae. Sampling techniques for examining the patterns of postlarval immigration into the Norman River estuary early in the study have been described by Staples (1980a). Plankton nets towed at 3 depths $(1,3,5 \mathrm{~m})$ near the estuary mouth were used to analyse the basic diel, tidal, and seasonal cycles of postlarval immigration during 1975-1976. Over the following $3 \mathrm{yr}$, postlarvae were sampled with an array of stationary plankton nets moored in the estuary $2 \mathrm{~km}$ upstream from the mouth (Fig. 1a,b). Seven sites could be used for sampling, 3 nets covering 3 depth strata at the mid-channel loca- 
Fig. 1. (a) Penaeus merguiensis. Study area for examining immigration of postlarvae into the Norman River, Gulf of Carpentaria. (b) Array of 7 set nets used to sample immigrating postlarvae

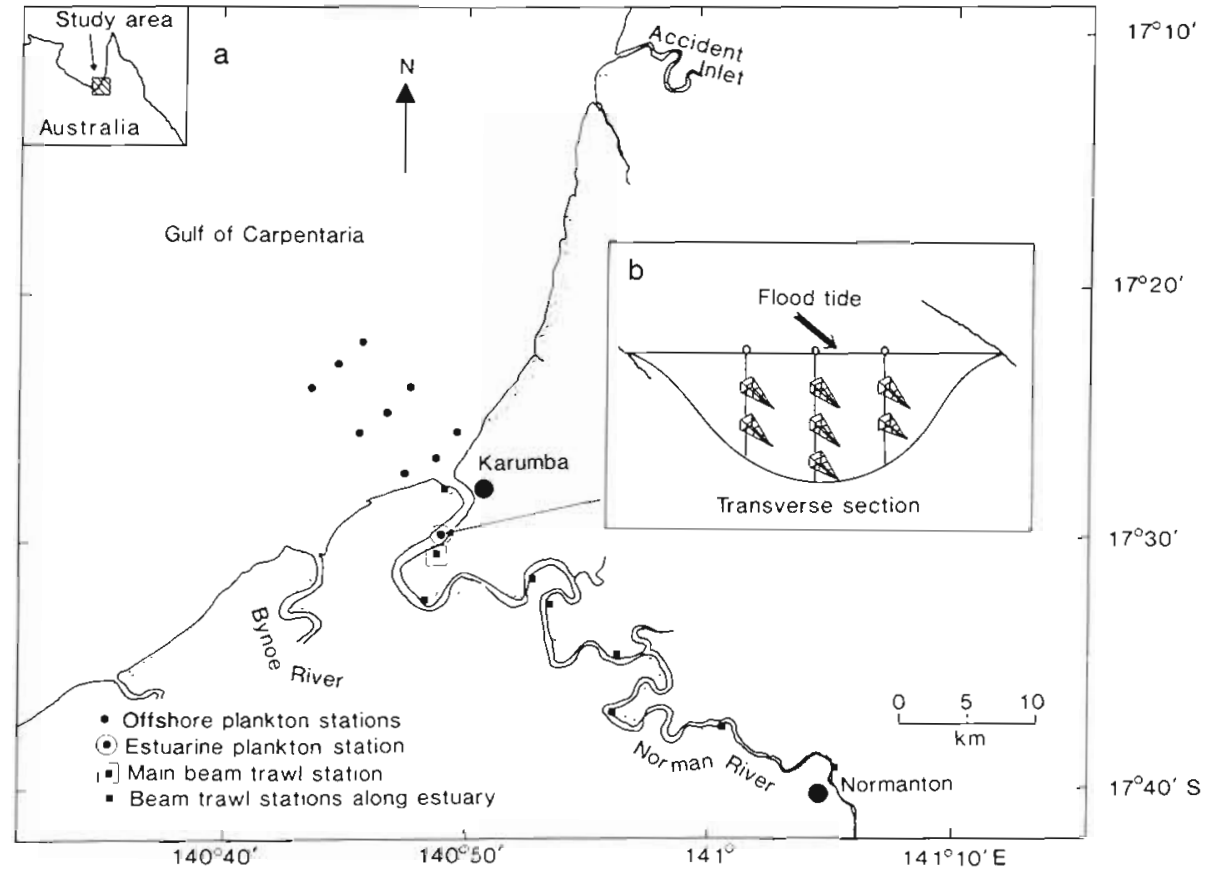

tion $(1,3,5 \mathrm{~m})$ and 2 nets at each of the other 2 shallower locations ( 1 and $3 \mathrm{~m}$ depths). Each sample consisted of lowering the nets into the flood tide current for 10 to $20 \mathrm{~min}$, depending on current speed.

Sampling was stratified in time to examine the variation in postlarval immigration on a series of time scales ranging from hourly changes during a tidal cycle to year-to-year differences. The basic sampling strategy carried out from October to May each year was to deploy at least 3 nets covering the 3 depth strata at the mid-channel location twice weekly to coincide with changes in lunar and tidal phases (new, first, full and last moon are not in phase with the neap-spring tidal changes in this region). From October 1976 to March 1977 extra sampling was conducted once each week to examine tidal patterns of immigration by setting nets every $2 \mathrm{~h}$ over the $12 \mathrm{~h}$ flood tide period. All other sampling during the study was carried out at the peak of the flood tide. Day-to-day variability was examined during the following year (Oct 1977 to Mar 1978) by setting nets every second day. An array of 7 nets was used each week from October to January in all years to provide information on the depth and lateral distribution of postlarvae. During winter (Jun to Aug), sampling was reduced to one net set weekly at the middle depth of the mid-channel location.

Environmental data including hourly records of rainfall, air temperature, wind speed and direction, water temperature, salinity, and limited records of current speed and direction as well as tide height were also collected (Staples 1983). Additional recordings of water temperature, salinity, and light penetration (Sec- chi disc) were made concomitant with plankton sampling.

Benthic postlarvae. The number of postlarvae which successfully settled on the banks of the estuary was estimated using beam trawl samples taken with a rectangular beam trawl $(0.5 \times 1.0 \mathrm{~m})$ fitted with a $2 \mathrm{~mm}$ mesh net and $1 \mathrm{~mm}$ mesh cod end. Weekly samples were taken at the time of low tide on a fixed station situated $2 \mathrm{~km}$ from the river's mouth (Fig. 1a) while 8 stations approximately $10 \mathrm{~km}$ apart up the estuary were sampled every $3 \mathrm{wk}$ on alternate neap and spring tides. During periods of low prawn numbers, the net was towed with the current 2 to $3 \mathrm{~m}$ from the bank over a distance of $200 \mathrm{~m}$. When densities were high, a series of 4 samples were taken randomly within the $200 \mathrm{~m}$ station by pulling the net perpendicular to the bank from the water's edge to a point $15 \mathrm{~m}$ towards the middle of the river (Staples \& Vance 1979). The number of Penaeus merguiensis with a carapace length less than $3 \mathrm{~mm}$ caught at the river mouth site was used as an index of settlement after allowance had been made for seasonal differences in the upstream distribution of postlarvae (no $\mathrm{m}^{-2}$ caught at mouth site $\times$ proportion of the upstream distance of river occupied by postlarvae).

Statistical analyses. Both the rate of postlarval immigration (no caught $\mathrm{min}^{-1}$ ) and density (no caught $10 \mathrm{~m}^{-3}$ of water filtered by the nets) were used in analyses and a variety of tests were used to describe patterns and significance testing. These included both orthogonal and non-orthogonal analysis of variance (Winer 1971, Underwood 1981) time series analyses 
(autocorrelation and spectral analysis) (Chatfield 1975), and multiple regression techniques (Draper \& Smith 1966). Counts of postlarvae were extremely variable and contained a large number of zeros. In most analyses covering short time scales, square root transformations were sufficient to stabilize variances. In longer time series, fourth root transformations were often necessary.

One of the statistical tools used in the study was a non-orthogonal multi-factorial anova model without replication. Several authors have pointed out (e.g. Winer 1971) that complete interpretation of these analyses, especially significance testing, is not particularly reliable. When used as a guide for demonstrating the importance of different factors and interactions, however, the technique forms a powerful analysis of complex environmental effects which otherwise may remain undetected. Rules for significance testing and pooling within the analysis are based on those given by Winer (1971) and Underwood (1981).

\section{RESULTS}

\section{Environmental characteristics}

A full account of the climate at Karumba and hydrology of the Norman River mouth has been published by Staples (1983). A summary of weekly rainfall, mean
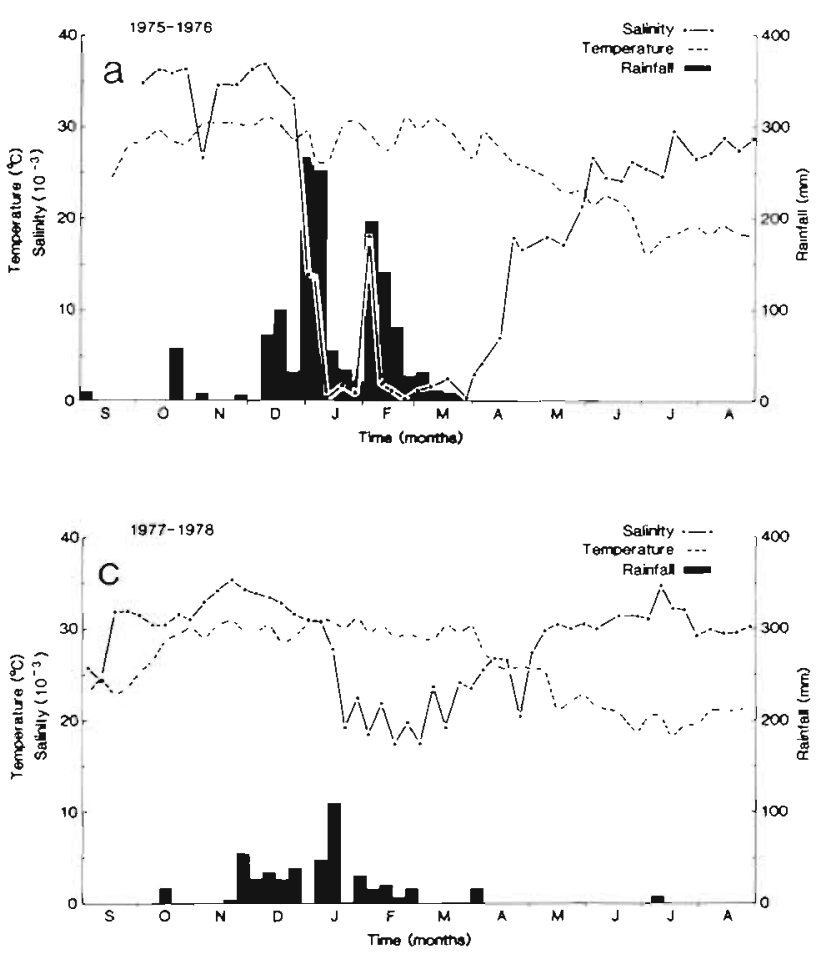

Fig. 2. Weekly rainfall, mean water temperature and salinity. water temperature and salinity for the four years of the study period is given in Fig. 2. Marked seasonal changes in rainfall, salinity, and water temperature were apparent in all years, although considerable year-to-year variation occurred. Mean annual rainfall over the study period was $1,044 \mathrm{~mm}$, of which over $80 \%$ occurred between December and March each year. Considerable inter-annual variation in rainfall was recorded which appeared to be related to the larger climatic changes seen in the South Pacific region over the period (as recorded by the Southern Oscillation Index) (Quinn \& Neal 1983). Rainfall in 1975-76 (Fig. 2a) was well above average (1421 $\mathrm{mm}$ ) and salinity at the estuary mouth decreased rapidly from $36.3 \times 10^{-3}$ to near zero during December 1975 . Apart from a small pulse of seawater in early February, near freshwater conditions prevailed until late March. Rainfall in 1976-77 (Fig. 2b) and 1978-79 (Fig. 2d) were close to average (1142 mm and $1091 \mathrm{~mm}$, respectively) and during both these years freshwater conditions occurred only during late February and March. The wet season of 1978-79 began later than that of 1976-77 and salinities remained higher for much of December and January. Following the El Niño event of 1977-78 the Southern Oscillation index remained low from March 1977 to April 1978. Over this period, rainfall was only $482 \mathrm{~mm}$ (Fig. 2c) and salinities remained high, even during the wet season (ca $20 \times 10^{-3}$ ).

After the wet season each year, salinities increased,
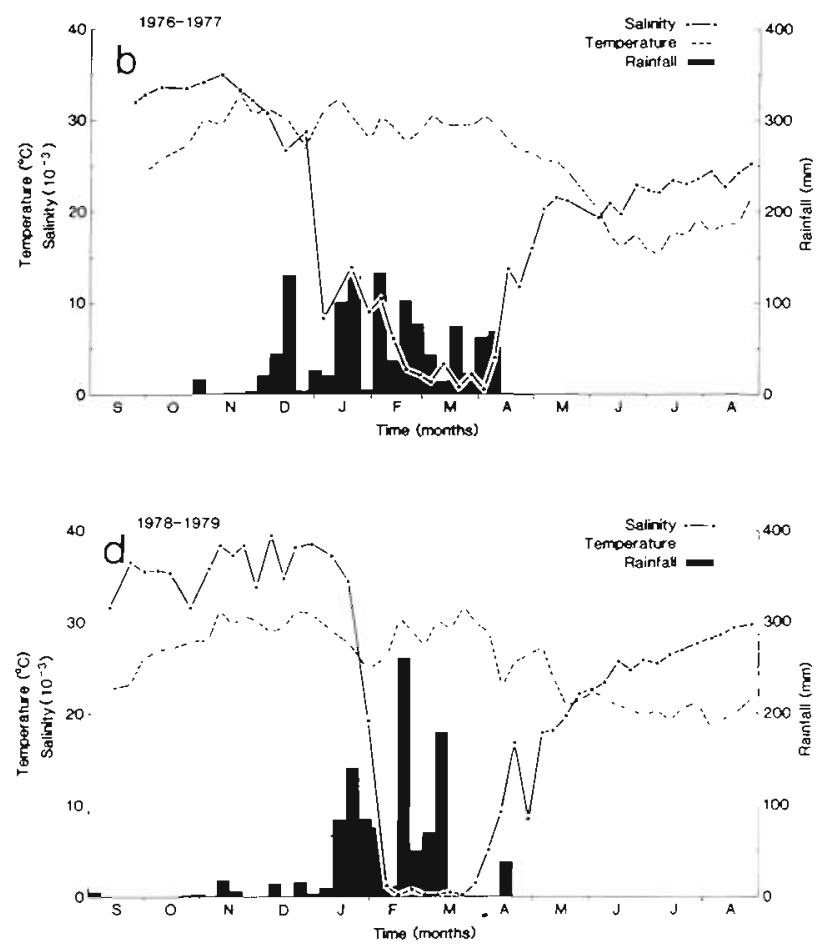

(a) 1975-76; (b) 1976-1977; (c) 1977-1978; (d) 1978-1979 
reaching a maximum in November-December. This maximum salinity was inversely related to the rainfall of the previous wet season and ranged from $35.0 \times$ $10^{-3}$ following years of good rainfall (e.g. Nov 1977 , Fig. 2c) to $39.6 \times 10^{-3}$ following the year of poor rainfall (Dec 1978, Fig. 2d).

Year-to-year differences in water temperature in the order of 2 to $3{ }^{\circ} \mathrm{C}$ were also correlated with these differences in rainfall and salinity (Staples 1983). Water temperatures were above normal for much of 1977-78 with a maximum occurring in January and a mininum in July. During years of higher rainfall, water temperatures were depressed throughout the summer wet season resulting in 2 maxima each year, one in the premonsoon month of November and the other in March-April. The lowest weekly water temperature recorded during the study was $15.4^{\circ} \mathrm{C}$ in June of 1977 and the highest was $33.2^{\circ} \mathrm{C}$ in November 1976. The annual range between winter minimum and springsummer maximum were $15.6,17.0,13.1$ and $13.4^{\circ} \mathrm{C}$ for the 4 yr, respectively.

\section{Offshore vertical migratory behaviour of postlarvae}

The effects of distance from shore (station), depth of water and time of day on the number of postlarval Penaeus merguiensis caught during the $24 \mathrm{~h}$ sampling were examined by analysis of variance. Preliminary orthogonal analysis showed that much of the variation in square root transformed postlarval densities was associated with station and depth interactions. Because sampling was sequential and cyclic behaviour was expected, time was fitted as a function of $\cos$ and

Table 1. Penaeus merguiensis. Analysis of variance of squareroot-transformed catch of postlarvae with distance from shore (station), water depth, and time of day (d.f. = degrees of freedom, $\mathrm{SS}=$ sums of squares, and $\mathrm{MS}=$ mean squares)

\begin{tabular}{|lrrrc|}
\hline Source of variation & d.f. & SS & MS & F-ratio \\
\hline Station & 2 & 7.559 & 3.779 & $5.62 \cdots$ \\
Depth & 2 & 5.920 & 2.960 & - \\
Station $\times$ depth & 4 & 0.840 & 0.210 & $<1 \mathrm{~ns}$ \\
Time & 4 & 6.619 & 1.655 & - \\
Sampling time & 8 & 1.428 & 0.178 & $<1 \mathrm{~ns}$ \\
Station $\times$ time & 4 & 6.725 & 1.681 & $2.50 \mathrm{~ns}$ \\
Station $\times$ sampling time & 20 & 15.930 & 0.797 & $1.18 \mathrm{~ns}$ \\
Depth $\times$ time & 4 & 17.125 & 4.281 & $6.36 \cdot$ \\
Depth $\times$ sampling time & 20 & 10.052 & 0.503 & $<1 \mathrm{~ns}$ \\
Station $\times$ depth $\times$ time & 8 & 2.224 & 0.278 & $<1 \mathrm{~ns}$ \\
Error & 40 & 26.915 & 0.673 & \\
& & & & \\
\hline ns not significant & & & & \\
. $\quad .01<\mathrm{P}<0.05$ & & & & \\
$\cdots \quad \mathrm{P}<0.01$ & & & & \\
\hline
\end{tabular}

$\sin \alpha$ and $2 \alpha$ (where $\alpha=2 \pi$ (hours/24). Two curves with periods of $12 \mathrm{~h}$ and $24 \mathrm{~h}$ were sufficient to explain a large part of the observed variance $($ d.f. $=4)$. In the combined analysis of variance, only the main station effect and the depth $\times$ time interaction were significant $\mathrm{P}<0.05$ ) (Table 1). Thus, although postlarval numbers differed significantly with distance from the coast, the station interactions were not significant. It was concluded that postlarval behaviour was similar at each station and results grouped over all stations adequately described the overall cycles of abundance and vertical distribution (Fig. 3a,b). Postlarval numbers were variable over the $24 \mathrm{~h}$ period (Fig. 3a) but not significantly different. The changes in depth distribution (Fig. 3b), therefore, could be ascribed to vertical migration. Postlarvae remained near the substrate from the start of sampling at $0600 \mathrm{~h}$ until $1000 \mathrm{~h}$ after which
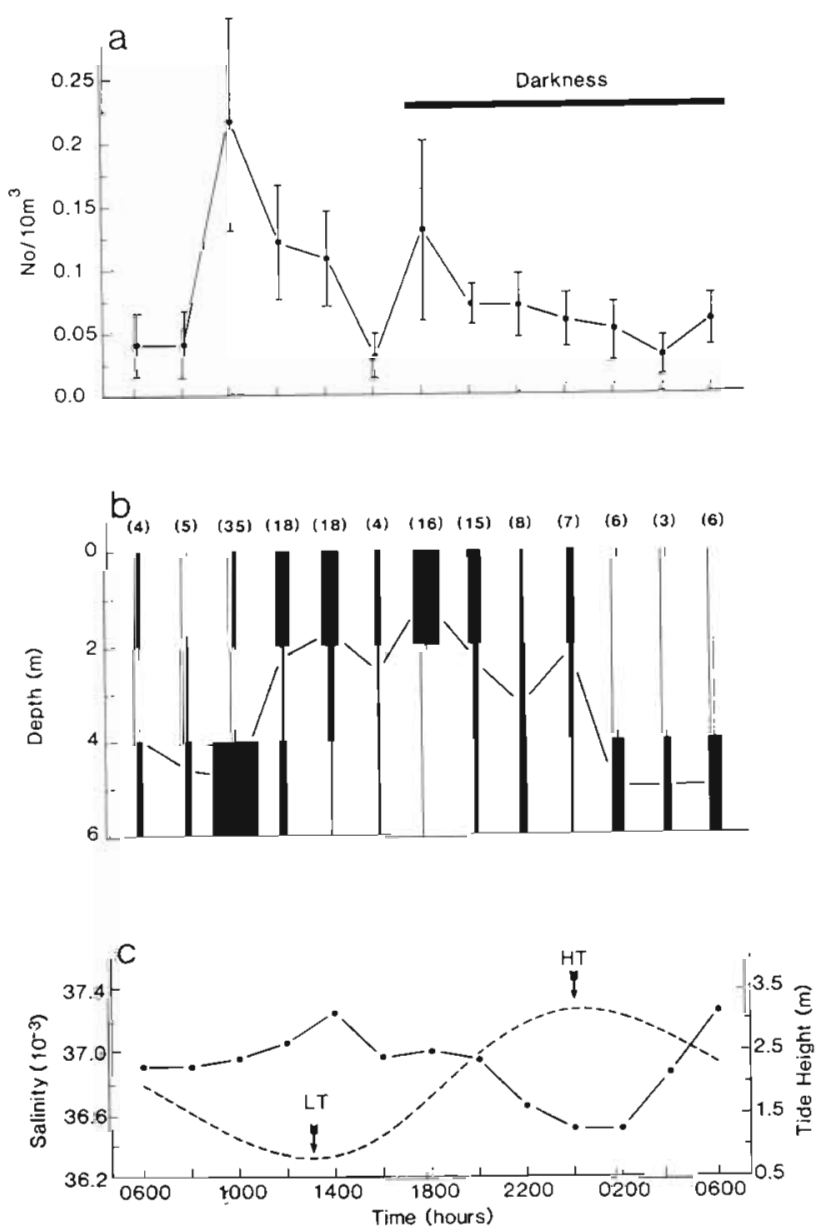

Fig. 3. Penaeus merguiensis. (a) Density of postlarvae (no $10 \mathrm{~m}^{-3}$ ) collected at 2-hourly intervals over 3 stations and 3 depths offshore from the Norman River, 23-24 Nov. 78; vertical bars: \pm 1 standard error. (b) Depth distribution at 2-hourly intervals, 23-24 Nov 78, Numbers in brackets: sample size. (c) Tide height (broken line) and salinity (solid line) at time of sampling 
they migrated towards the surface just before low tide. They then remained high in the water column throughout most of the flood tide, dropping back to near the substrate after high tide at $0200 \mathrm{~h}$. High and low slack water (times of no current flow) with associated changes in salinity occurred 1 to $2 \mathrm{~h}$ after high and low tide heights, respectively. Changes in larval behaviour appeared to be cued more closely to changes in tide heights than the current direction changes. No changes were associated with changes in the day/ night cycle.

Postlarval abundance and depth distribution on the intertidal flats each side of the main offshore channel did not differ from that recorded in the channel at the same time ( $F$ values for differences in abundance between stations $=1.18$ and $<1.0$ for low tide and high tide samplings, respectively, d.f. $=8,16$; $\mathrm{P}<0.05)$.

\section{Depth and lateral distribution of immigrating postlarvae}

Depth distribution of postlarvae while passing through the estuary mouth was also examined over several time scales. During a series of three $12 \mathrm{~h}$ flood tide periods in spring 1976 postlarvae occurred high in the water column except for the first $2 \mathrm{~h}$ after low tide (Table 2). Both date and stage of tide significantly affected postlarval numbers $(P<0.05)$. These effects are discussed in full in later sections. Of relevance here is the insignificant depth $\times$ tide stage interaction $(F=$ 1.352 , d.f. $=8,16 ; \mathrm{P}>0.05$ ), which suggests that the depth distribution of postlarvae did not change significantly throughout the flood tide period. During this season, postlarvae appeared more abundant higher in the water column, a behaviour similar to that observed further offshore.

Table 2. Penaeus merguiensis. Depth distribution of immigrating postlarvae throughout the flood tide period $(\mathrm{N}=3)$. Postlarval abundance expressed as mean no $10 \mathrm{~m}^{-3}$. Percentage distribution by depth shown in parentheses

\begin{tabular}{|lccccc|}
\hline & \multicolumn{6}{c|}{ Tidal stage (hours past low slack water) } \\
& 2 & 4 & 6 & 8 & 10 \\
\hline Depth & & & & & \\
Surface (1 m) & 0.07 & 3.01 & 0.80 & 0.37 & 0.12 \\
& $(2.3)$ & $(52.4)$ & $(43.0)$ & $(48.7)$ & $(46.2)$ \\
Mid-water (3 m) & 1.12 & 1.42 & 0.63 & 0.29 & 0.0 \\
& $(37.6)$ & $(24.8)$ & $(33.4)$ & $(38.2)$ & $(0)$ \\
Near substrate & 1.79 & 1.31 & 0.43 & 0.10 & 0.14 \\
$\quad(5$ m) & $(60.1)$ & $(22.8)$ & $(23.1)$ & $(13.1)$ & $(53.8)$ \\
Mean depth (m) & 4.3 & 2.4 & 2.6 & 2.3 & 3.2 \\
& & & & & \\
\hline
\end{tabular}
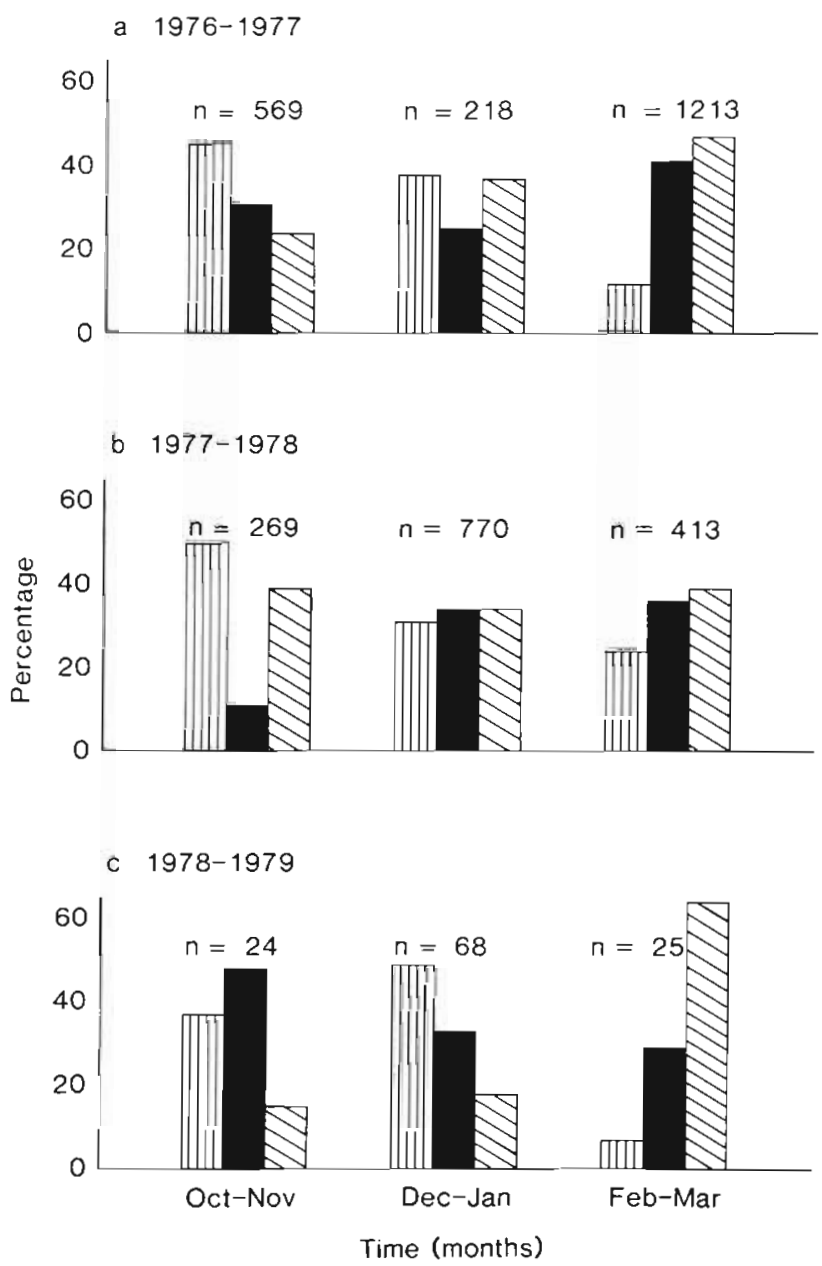

Fig. 4. Penaeus merguiensis. Percentage depth distribution of immigrating postlarvae (a) 1976-1977; (b) 1977-1978; (c) 1978-1979; $\mathrm{n}=$ number of postlarvae observed. Vertical hatching: top; solid hatching: middle; diagonal hatching: bottom

Postlarvae collected in 1975-76 showed a significant change in depth distribution as the seasons progressed from the dry pre-monsoon period (Oct-Nov) through to the wet monsoon period (Feb-Mar) (Staples 1980a). Postlarvae sampled over the following $3 \mathrm{yr}$ were also lower in the water column during February-March although considerable year-to-year variation occurred (Fig. 4). The effect was greatest during the wetter years of $1976-77$ and 1978-79 than during the dry year of $1977-78$.

Cross-channel location was also examined. The cross-section of the river at the point of sampling was not completely symmetrical, the main channel lying slightly closer to the eastern bank. During the springearly summer months when the full complement of 7 nets were used to sample postlarvae, there was a tendency for the postlarval density to be higher towards the eastern bank and lower nearer the western bank 
Table 3. Penaeus merguiensis. Mean number of postlarvae (no $10 \mathrm{~m}^{-3}$ ) taken in each of 7 nets spanning the Norman River estuary mouth. ( $\mathrm{N}=$ number of samples)

\begin{tabular}{|c|c|c|c|c|}
\hline \multirow{2}{*}{$\begin{array}{c}\text { Depth } \\
(\mathrm{m})\end{array}$} & \multirow{2}{*}{ Year } & \multicolumn{3}{|c|}{ Cross channel location } \\
\hline & & East & Mid-river & West \\
\hline \multicolumn{5}{|c|}{$1976-77$} \\
\hline 1 & & 1.01 & 0.57 & 0.44 \\
\hline 3 & & 0.96 & 0.66 & 0.19 \\
\hline \multirow[t]{2}{*}{5} & & $-\cdot$ & 0.46 & $-\cdot$ \\
\hline & $1977-78$ & & & \\
\hline 1 & & 1.42 & 0.90 & 0.25 \\
\hline 3 & & 0.49 & 0.72 & 0.70 \\
\hline \multirow[t]{2}{*}{5} & & $-\cdot$ & 0.44 & $-\cdot$ \\
\hline & $1978-79$ & & & \\
\hline 1 & & 0.51 & 0.25 & 0.09 \\
\hline 3 & & 0.14 & 0.08 & 0.14 \\
\hline \multirow[t]{3}{*}{5} & & $-\cdot$ & 0.04 & $-\bullet$ \\
\hline & Mean & 0.76 & 0.46 & 0.30 \\
\hline & $\mathrm{N}$ & 11 & 49 & 20 \\
\hline \multicolumn{5}{|c|}{$\begin{array}{l}\text { This depth strata not represented in locations closer to } \\
\text { river bank }\end{array}$} \\
\hline
\end{tabular}

(Table 3). Considerable sample to sample variation occurred, however, and the effect was statistically significant only in 1978-79 $(\mathrm{F}=7.12$, d.f. $=2,139$; $\mathrm{P}<0.01$ ). In all years of sampling, the mean catches over depth taken from the mid-channel location were intermediate in value between the eastern and western bank locations, and were used as an index of postlarval immigration over longer time series.

\section{Tidal and diel periodicity of immigration}

Tidal periodicity in the ingress of postlarval Penaeus merguiensis into the Norman River over one $24 \mathrm{~h}$ sampling period on 20th November 1975 was described by Staples (1980a). Postlarval immigration on this occasion was restricted to the flood tide period, with a peak of immigration occurring around the middle of the tide at the time of maximum current velocity. The tide was a typical diurnal type, falling between the neap and spring tide phase periods. Tides in the Norman River are predominantly diurnal, although semidiurnal tides can occur for short periods during the neap tide phase. During both the $12 \mathrm{~h}$ diurnal tide of the springs (Fig. 5a) and the $6 \mathrm{~h}$ semidiurnal tide of the neaps (Fig. 5c) sampled in 1976-77, both current velocities and postlarval immigration were distributed symmetrically over the flood tide period, the mode in postlarvae corresponding to the time of maximum tide velocity. Between the neap and spring tide phases, both postlarval immigration and current velocity curves were flatter with similar rates occurring for

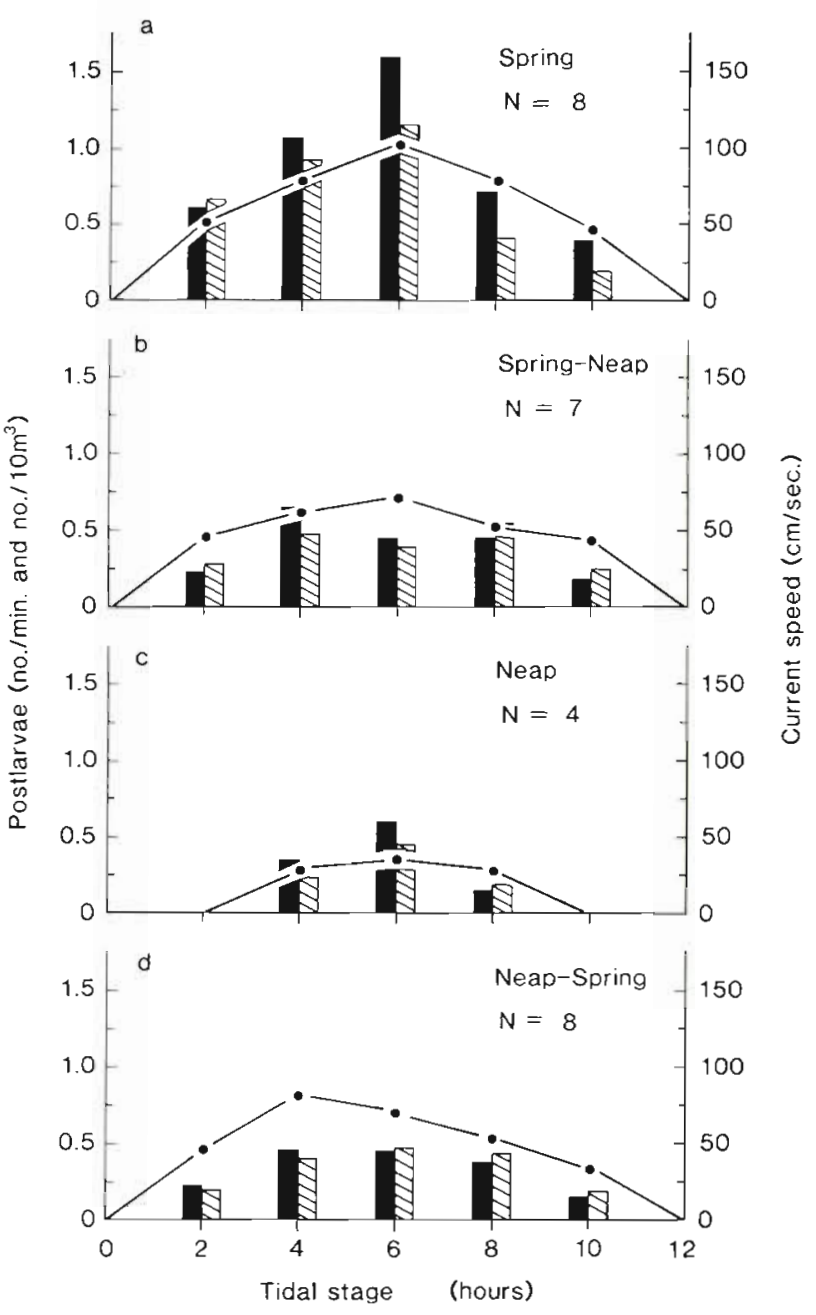

Fig. 5. Penaeus merguiensis. Distribution of water velocity and postlarvae over the flood tide period recorded during spring, neap and intermediate tide phases. $\mathrm{N}=$ number of tide phases observed. Solid line: current speed; solid histogram: number $\mathrm{min}^{-1}$; cross-hatched histogram: number $10^{-3}$. Tidal stage is hours after low slack water

periods of 4 to $6 \mathrm{~h}$ around mid-tide. After the effects of tidal stage were removed, no significant day or night effect could be demonstrated $(F=1.60$, d.f. $=4,16$, $P>0.05$ ).

A reliable index of immigration can be obtained, with a large reduction in sampling effort, by measuring only the immigration at the time of maximum current velocity. Slight underestimates of immigration will occur during the period between the neaps and springs due to the flatter nature of the curves during these times. Compared with the natural variability in postlarval abundances, however, this does not introduce serious error and the technique was adopted for the remainder of the study. The method has the added advantage that the indices on both semidiurnal and diurnal tide are directly comparable. 


\section{Tidal and lunar cycles of immigration}

The short-term variation in the number of postlarval Penaeus merguiensis entering the estuary were examined firstly from the samples taken every second day during 1977-78. Immigration of postlarvae, expressed both as rate (no $\mathrm{min}^{-1}$ ) and density (no $10 \mathrm{~m}^{-3}$ ) showed extreme variability over the sampling period (Fig. 6) with narrow peaks coinciding roughly with times of spring tides. As the number of postlarvae entering the estuary per minute is dependent on current velocity, peaks corresponding to spring tides in the rate data were not unexpected. However, after correcting for these current differences by calculating the number $10 \mathrm{~m}^{-3}$ water filtered, peaks in abundance

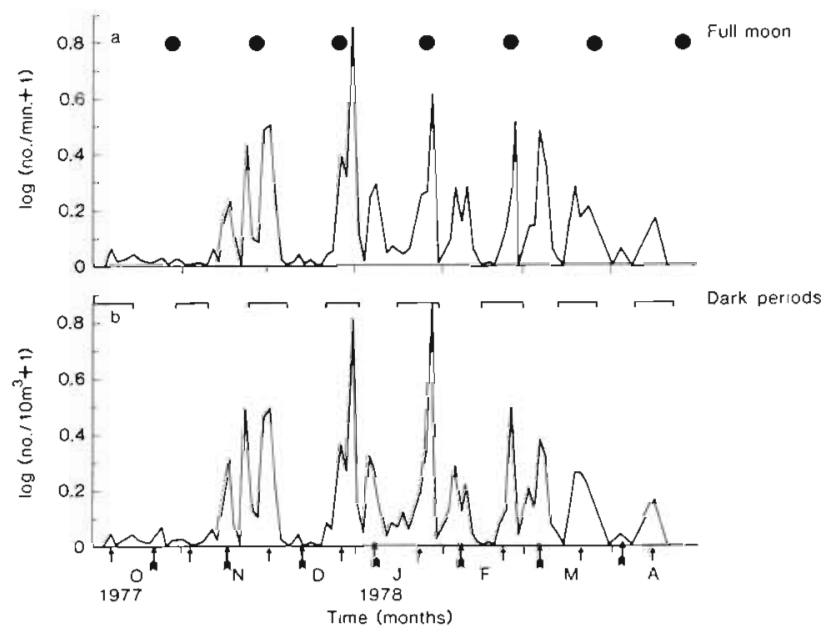

Fig. 6. Penaeus merguiensis, Short-term variability in (a) rate of immigration and (b) density of postlarvae at the time of peak flood-tide current velocity from October 1977 to April 1978. Arrows: time of spring-tide phases. Larger arrows coincide with spring tides of larger tidal heights. Bars of darkness refer to periods when high tide coincides with time of moonrise

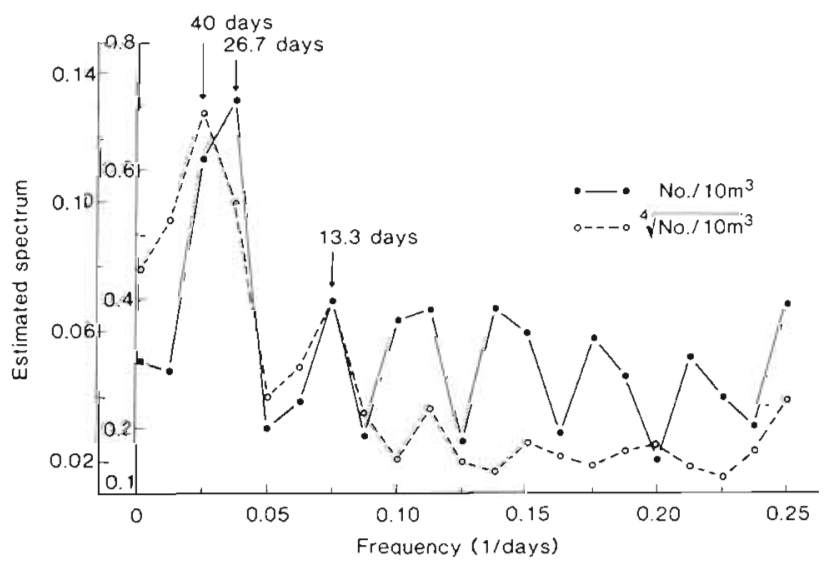

Fig. 7. Penaeus merguiensis. Spectral analysis of short-term variation in density of postlarvae. Solid line: untransformed data; dotted line: fourth-root-transformed data still existed. Spectral analysis of untransformed data exhibited peaks at 13.3 and 26.7 d (Fig. 7) indicating that immigration of postlarvae during 1977-78 was in phase with the neap-spring tide cycle in the southeastern Gulf which exhibits a periodicity of $13.66 \mathrm{~d}$ (Forbes \& Church 1983). Fourth root transformation of the data resulted in less variation in the higher frequencies but shifted the low frequency peak to $40 \mathrm{~d}$ (Fig. 7). These different results with different transformations demonstrate the uncertainty in describing exact periodicities in the data, especially at higher and lower frequencies. Autocorrelation analysis of density data revealed a strong peak at $28 \mathrm{~d}$. These analyses were taken to indicate that more postlarvae immigrated into the estuary on the spring tide, with larger peaks corresponding to every second spring tide period. In the Norman River, the tidal range of every second spring tide is larger than that of the preceding spring period. Increase in postlarval abundance appeared to coincide with the smaller of the 2 spring tide ranges (Fig. 6). This was supported by regression analysis techniques using both transformed density and rate data. Tide height significantly reduced the variance seen in the original data $(\mathrm{P}<0.01)$ but residuals still exhibited an apparent 27 to $28 \mathrm{~d}$ cycle. The variance could be further reduced by introducing a $14 \mathrm{~d}$ time lag so that peaks of postlarvae corresponded to spring tides with the larger tide heights. Postlarval immigration, therefore, was not simply a function of tide height. In the case for this single year's data an interaction between lunar phase and tidal phase is suggested. The main peaks of postlarvae coincided approximately with the time of full moon, although the two were not entirely synchronous (peaks of postlarvae occurred every 27 to $28 \mathrm{~d}$, whereas the moonphase cycle changes every $29.53 \mathrm{~d}$ ). Another hypothesis involving the timing of moon rise and moon set in relation to the time of high and low tides was also considered. During one tidal phase cycle (one neap tide to the next) the time of high tide corresponds to the time of moon rise while for the next cycle, high tide corresponds to moon set. A 2-wk period of 'dark' flood tides, therefore, alternates with a period of 'light' flood tides. The 27 to $28 \mathrm{~d}$ peaks in postlarval immigration always occurred during the spring tide associated with the 'dark' period of the month.

These hypotheses were examined further by extending the regression analyses to include the data collected over the 3 yr period from September 1976 to March 1979. The first step in the analysis was to relate density of postlarvae to tide height lagged from 0 to $30 \mathrm{~d}$ before postlarval sampling. Correlation coefficients (Table 4 ) showed that over all years, the highest correlation occurred between density data and tide height lagged $14 \mathrm{~d}$, thus supporting the earlier obser- 
Table 4. Penaeus merguiensis. Simple correlation coefficient between fourth-root-transformed density of postlarvae, tide height and wind speed lagged for periods of 0 to $30 \mathrm{~d}$ before each sampling date

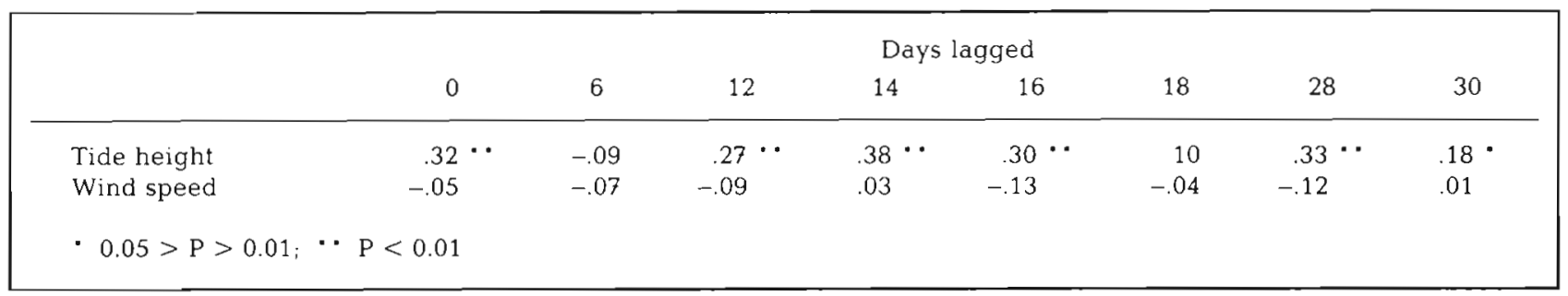

Table 5. Penaeus merguiensis. Analysis of variance of postlarval density over the period September 1976 to March 1979 . Data transformed by fourth root before analysis (d.f. = degrees of freedom)

\begin{tabular}{|c|c|c|c|c|}
\hline Variable & d.f. & Sums of squares & Mean squares & F ratio \\
\hline Tide $^{+}$ & 1 & 3.327 & 3.327 & $31.20^{\cdots}$ \\
\hline Moon & 2 & 0.676 & 0.338 & 3.17 \\
\hline Moon $\times$ tide & 2 & 0.276 & 0.136 & $1.29 \mathrm{~ns}$ \\
\hline Year & 2 & 3.755 & 1.877 & $17.61 \cdots$ \\
\hline Tide $\times$ year & 2 & 0.428 & 0.249 & $2.34 \mathrm{~ns}$ \\
\hline Moon $x$ year & 4 & 0.906 & 0.226 & $2.12 \mathrm{~ns}$ \\
\hline ErTor & 142 & 15.139 & 0.107 & \\
\hline
\end{tabular}
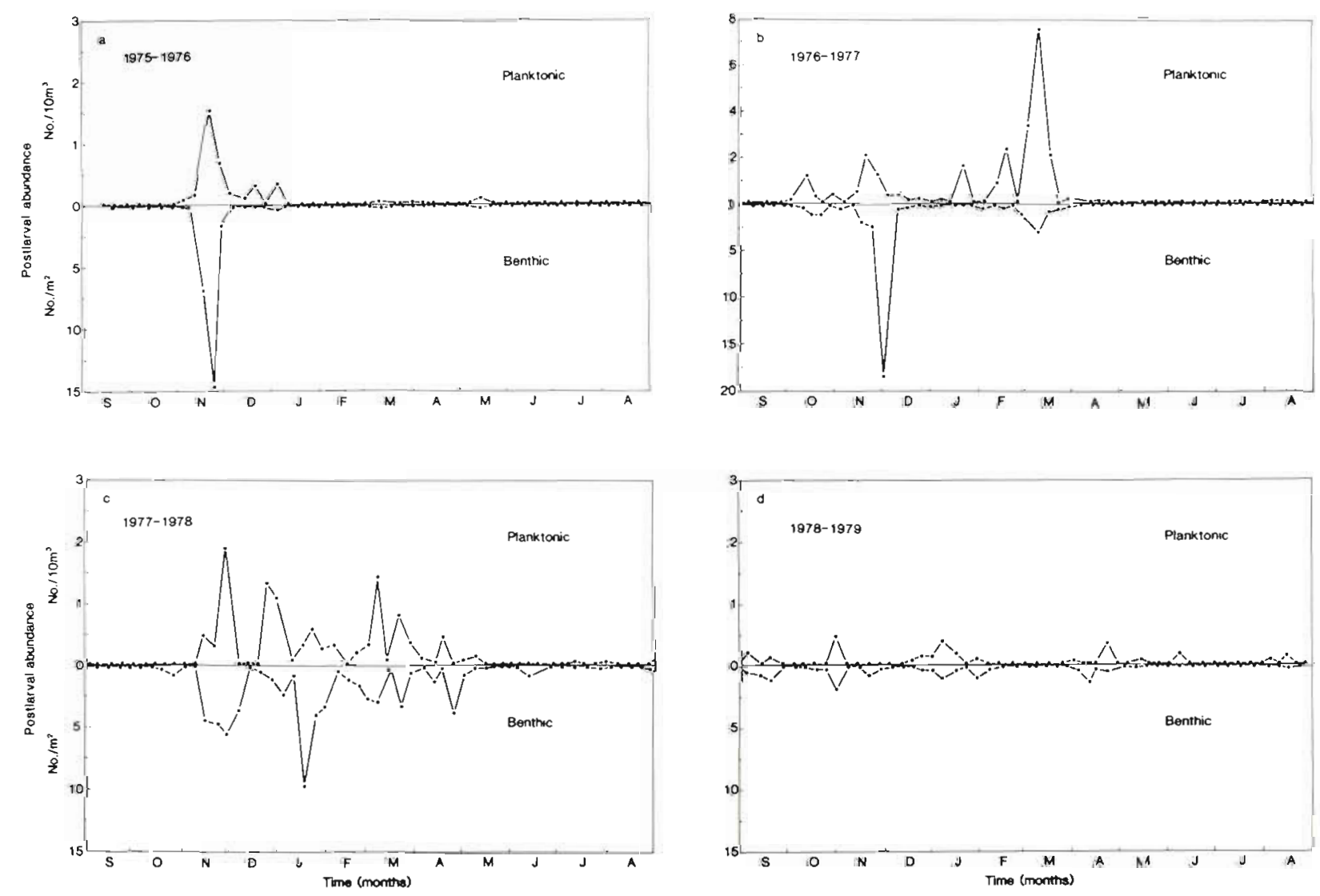

Fig. 8. Penaeus merguiensis. Seasonal distribution of immigrating postlarvae. (a) 1975-1976; (b) 1976-1977; (c) 1977-1978; (d) 1978-1979. Solid line above zero: planktonic postlarvae: Solid line below zero: newly settled benthic postlarvae 
vation that postlarval immigration was higher during the smaller of the 2 spring tide periods each month. As noted above, the period of the smaller spring tide height also coincided with the 'dark' period of the tidal month. The effect of moon phase and lagged moon phase was examined by simulating moon phase change using both a sine curve and a cosine curve with a periodicity of $29.53 \mathrm{~d}$. Analysis of variance showed that as well as lagged tide height (d.f. $=1$ ), moon phase (sine curve [d.f. $=2]$ ) and year of sampling (d.f. $=2$ ) both significantly affected postlarval immigration (Table 5). The observations made in 1977-78, however, that spring tides coinciding with full moons evoked higher immigration did not follow for other years, and over the $3 \mathrm{yr}$, the interaction between moon phase and tide phase was not significant (Table 5).

Several other environmental variables were examined to determine their effects on postlarval immigration. These included wind (on/offshore and longshore components as well as mean vector speed and direction), and salinity. No effects on immigration could be detected for any of these factors (e.g. wind speed; Table 4).

\section{Seasonal periodicity of immigration and settlement}

Over all years, postlarval immigration was essentially confined to the period between October to April (Fig. 8). Water temperature during these periods of postlarval immigration was always in excess of $26^{\circ} \mathrm{C}$.

During 1975-76, postlarval immigration of Penaeus merguiensis into the Norman River was highly seasonal with one main peak in November and smaller pulses occurring in January, March, and May (Staples 1980a). These results are illustrated in Fig. 8a along with estimates of the number of benthic postlarvae ( $<3 \mathrm{~mm}$ carapace length) on the banks of the estuary during the same period. Rainfall during this year was well above average and as a result of large freshwater discharge, a physical barrier which prevented immigration was formed throughout much of January, February, and early March. Considerable year-to-year variation in this seasonal pattern of postlarval immigration occurred over the following $3 \mathrm{yr}$ (Fig. 8b,c,d) associated, in part, with variable rainfall patterns. In 1976-77 (Fig. 8b) both postlarval immigration and settlement were essentially bimodal with main peaks occurring in November and February-March. Rainfall during this year was average and the freshwater discharge prevented immigration for only short periods during January and late February. A much larger proportion of the spring postlarvae successfully settled compared with the autumn postlarvae in the postmonsoon months. During the exceptionally low rainfall year of 1977-78, postlarval immigration and settlement continued from November to April, with settlement proportional to immigration right throughout the period. During 1978-79, postlarval immigration was low and sporadic. Freshwater discharge from this average rainfall year prevented postlarval immigration throughout much of February and March.

\section{Year-to-year variation in postlarval immigration}

A wide variation in the index of postlarval recruitment between years was observed. Differences in the accumulated weekly immigration were apparent as early as the end of November, and diverged further with time (Fig. 9), Maximum immigration occurred in 1976-77, minimum immigration in 1978-79.

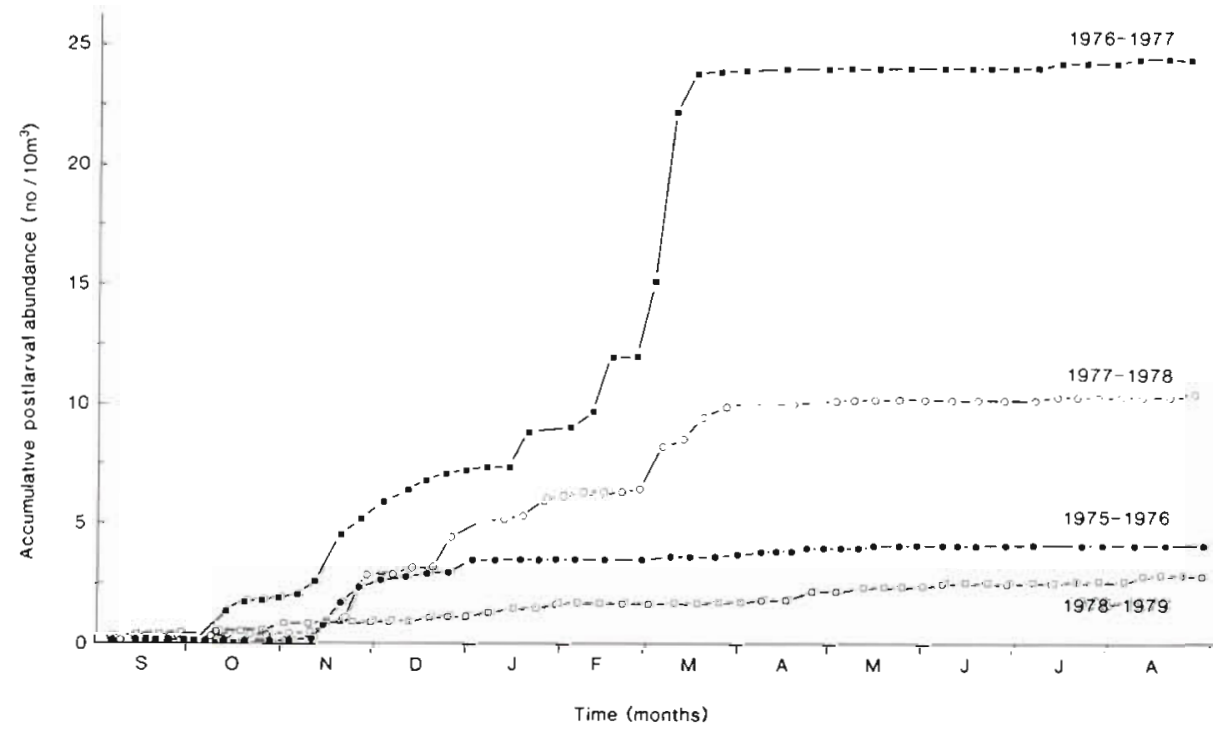

Fig. 9. Penaeus merguiensis. Accumulative weekly index of immigration of postlarvae for the 4 yr of study $1975-1979$ 
Table 6. Index of spring postlarval immigration (no $10 \mathrm{~m}^{-3}$, rainfall $(\mathrm{mm})$ of preceding wet season, salinity $\left(10^{-3}\right)$, water temperature $\left({ }^{\circ} \mathrm{C}\right)$, nutrients $(\mathrm{ppm})$, index of adult biomass (tonnes), and long-shore and on/off-shore wind components $\left(\mathrm{km} \mathrm{h}^{-1}\right)$ for the years 1975-1979, Norman River south-eastern Gulf of Carpentaria

\begin{tabular}{|ccccccccccc}
\hline Year & $\begin{array}{c}\text { Postlarval } \\
\text { index }\end{array}$ & $\begin{array}{c}\text { Rainfall } \\
\text { (previous } \\
\text { year) }\end{array}$ & Salinity & Temperature $\mathrm{NO}_{3}-\mathrm{N}$ & $\mathrm{SiO}_{2}-\mathrm{Si}$ & $\begin{array}{c}\text { Adult } \\
\text { yield }\end{array}$ & $\begin{array}{c}\text { Wind } \\
\text { long- } \\
\text { shore }\end{array}$ \\
\hline $1975-76$ & 3.38 & 774 & 34.2 & 28.6 & 3.67 & 46.23 & 735 & 9.0 & $\begin{array}{c}\text { Wind } \\
\text { on/off- } \\
\text { shore }\end{array}$ \\
$1976-77$ & 7.25 & 1386 & 32.3 & 26.6 & 6.23 & 34.57 & 1255 & 5.2 & 0.8 \\
$1977-78$ & 4.75 & 1101 & 31.3 & 25.3 & 8.90 & 55.57 & 2701 & 6.1 \\
$1978-79$ & 1.13 & 530 & 35.7 & 27.4 & 6.00 & 35.97 & 387 & 3.3 & 1.2 \\
\hline
\end{tabular}

Table 7. Penaeus merguiensis. Analysis of variance of changes in carapace length $(\mathrm{mm})$ and rostral spine number of immigrating postlarvae (d.f. = degrees of freedom, $\mathrm{SS}=$ sums of squares, and $\mathrm{MS}=$ mean squares)

\begin{tabular}{|c|c|c|c|c|c|c|c|}
\hline \multirow[b]{2}{*}{ Source of variation } & \multirow[b]{2}{*}{ d.f. } & \multicolumn{3}{|c|}{ Carapace Length } & \multicolumn{3}{|c|}{ Rostral Spine No. } \\
\hline & & SS & MS & F-ratio & SS & MS & F-ratio \\
\hline Year & 3 & 15.286 & 5.095 & - & 0.089 & 0.030 & - \\
\hline Month & 7 & 146.257 & 20.893 & - & 13.120 & 1.886 & - \\
\hline Year $\times$ month & 15 & 27.191 & 1.813 & $5.91 \cdots$ & 3.840 & 0.274 & $2.73^{\cdots} \cdot$ \\
\hline Season & 2 & 8.861 & 4.431 & - & 2.314 & 1.157 & - \\
\hline Tide & 3 & 6.567 & 2.189 & - & 1.824 & 0.608 & - \\
\hline Season $\times$ tide & 6 & 10.126 & 1.688 & $5.50^{\cdots}$ & 4.244 & 0.707 & $7.05 \cdots$ \\
\hline Moon & 3 & 3.294 & 1.018 & - & 0.556 & 0.185 & - \\
\hline Tide $\times$ moon & 9 & 5.755 & 0.639 & $2.08^{\circ}$ & 2.392 & 0.266 & $2.65 \cdots$ \\
\hline Error & 261 & 80.072 & 0.307 & & 25.290 & 0.100 & \\
\hline
\end{tabular}

In an attempt to explain these year-to-year differences, the accumulative index of postlarval immigration up to the end of December was compared with mean salinity, water temperature, nitrate nitrogen and silicate silicon concentrations, longshore and on/offshore wind components, total rainfall of the preceding wet season and an index of the offshore adult banana prawn abundance made 6 mo before the period of postlarval immigration as given by Somers \& Taylor (1981) (Table 6). Insufficient data points are available for statistical analyses, but the comparisons suggested that large immigration of postlarvae followed years of higher rainfall. Large immigration years, therefore, were also associated with lower salinity, lower water temperature and increased nutrient level of the estuary. Increased rainfall also resulted in increased offshore adult populations following the monsoon period (Vance et al. in press) and large scale immigration of postlarvae is therefore also associated with larger adult stocks.

As well as the effect of the previous season's rainfall, rainfall also directly affects postlarval immigration by the physical barrier effect described earlier. Within the same month low postlarval numbers occurred during periods of high rainfall but the reverse was not always the case. This factor alone, therefore, failed to explain why summer and autumn immigration differed so markedly from year to year.

\section{Changes in size and developmental stage of postlarvae}

Several factors affected the size and developmental stage of immigrating postlarvae (Table 7). These included year $x$ month interactions, season $x$ tideinteractions and tide $\times$ moon interactions. In this analysis, year, month and season, although not truly independent factors, were introduced into the model to reduce variation which could be mistakenly attributed to other factors such as tide and moon. The annual cycle (season) was fitted as a sine curve (d.f. $=2$ ), but a substantial amount of variation was still unaccounted for and year $x$ month effects were retained. Because of the large number of factors, only 2 factor-interactions were fitted. For both carapace length and spine number, the season $\times$ moon interactions were not significant and were dropped from the model but all other interactions were retained (Table 7). Although complicated by the interactions, the time of year postlarvae reached the river affected their size and development. Although the seasonal cycle of change 


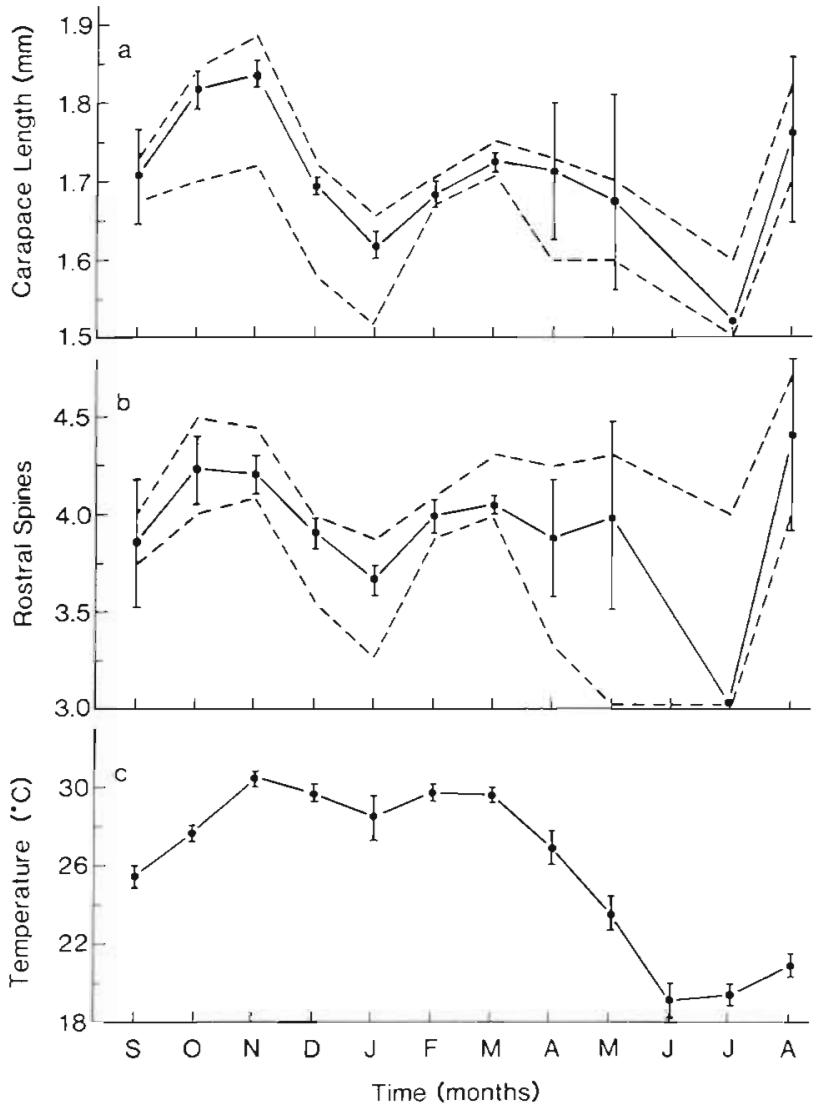

Fig. 10. Penaeus merguiensis. (a) Mean carapace length of postlarvae; (b) mean number of dorsal rostral spines; (c) seasonal water temperature over 4 yr (1975-1979). Solid line: weighted means for the $4 \mathrm{yr}$ period; broken line: ranges of means for each year; vertical bars: standard errors

differed in degree, a basic bimodal pattern was evident each year (Fig. 10a,b). Both carapace length and rostral spine numbers were higher in spring (Oct-Nov) and autumn (Mar-Apr). These variables were positively correlated with the seasonal temperature cycle (Fig. 10c) but only accounted for $20 \%$ of the observed variance. In particular, the size and stage of summer postlarvae were much lower than expected from temperature changes alone.

Over the $4 \mathrm{yr}$ of study, postlarval size ranged from $1.68 \pm 0.02 \mathrm{~mm}(\mathrm{n}=128)$ in $1978-79$ to $1.74 \pm 0.01$ ( $\mathrm{n}=1809$ ) in $1976-77$. The mean dorsal rostral spine number for the same years were $3.87 \pm 0.006$ and $4.11 \pm 0.12$, respectively. The larger postlarvae occurred in 1976-77 and 1977-78 which were the years of greater postlarval abundance. Growth as well as survival (see previous section) may be greater in years following heavier rainfall.

Over smaller time scales, both tidal phase and lunar phase affected postlarval size and stage. In general, postlarvae were larger and more well developed dur-

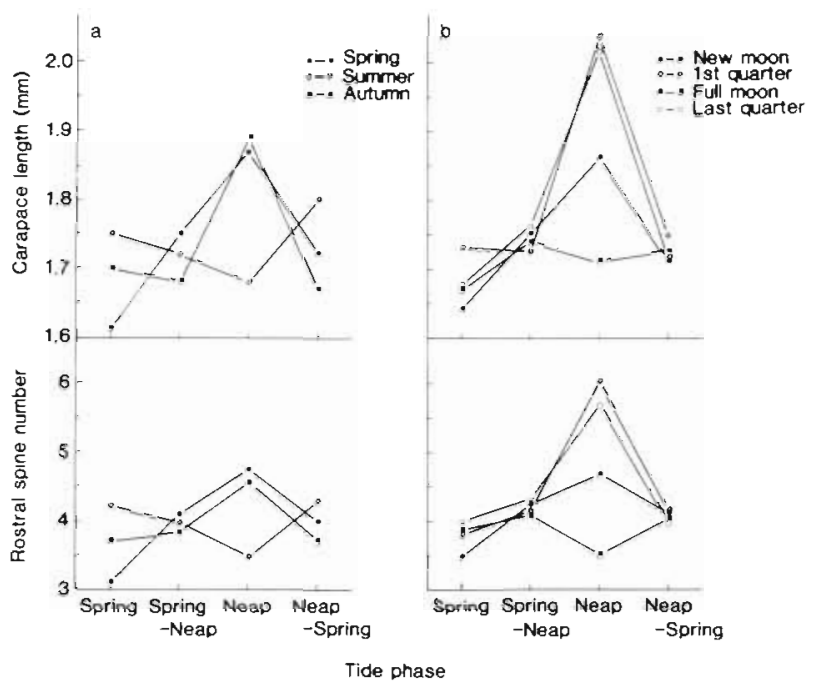

Fig. 11. Penaeus merguiensis. Ințeractions between (a) tide phase and season; (b) tide phase and lunar phase, on the mean carapace length and rostral spine number of immigrating postlarvae

ing the neap tide period than during the springs (Fig. 11), the exceptions being during the summer period and during the full moon. As shown earlier, more postlarvae immigrate during the spring tide phase. The smaller size of postlarvae during these phases suggest a more rapid migration from the spawning areas.

\section{DISCUSSION}

All penaeid prawn postlarvae appear to couple vertical migratory behaviour with passive utilization of tidal currents to facilitate their horizontal advection and immigration into estuarine nursery areas (for review see Garcia \& Le Reste 1981). Earlier larval stages (nauplius to mysis) migrate vertically in the water column in response to changing light intensity and disperse in the direction of the prevailing tidal current at night (Rothlisberg 1982). As the larvae develop and come closer to the shore, the vertical migration becomes more closely associated with changes in tidal cues. Hughes (1969) demonstrated that changes in salinity associated with changing tidal currents elicited a vertical migratory response in Penaeus duorarum postlarvae. In our study, P. merguiensis postlarvae up to $10 \mathrm{~km}$ offshore from the Norman River migrated vertically in response to tidal cues. The vertical migration was triggered during the last stages of the ebb tide several hours before salinity changes associated with changes in current direction were observed. A similar behaviour is suggested in the peak of catchability of benthic postlarvae and small 
juveniles seen in the later stages of the ebb tide along the banks of the Norman River (Staples \& Vance 1979). Chong (1979) also concluded for $P$. merguiensis that postlarvae were responding more to tide height changes than to any other factor in the nursery areas in the Straits of Malacca, where little change in salinity was observed between flood and ebb tides.

In comparison, Metapenaeus spp. collected off the Norman River during the same sampling period showed a much more marked diel cycle of postlarval abundance as well as differences in the pattern of vertical migration (unpubl.). Much larger numbers of postlarvae of this species occurred at night than during the day and postlarvae were in the water column for only a short period just before high tide. Generalizations concerning postlarval immigration are not possible without further detailed research.

Geographic differences within the same species are also apparent. For example, Chong (1979) reported that, in an area which experiences regular semi-diurnal tides, more Penaeus merguiensis postlarvae immigrated into the estuary at night than during the day. Postlarval ingress reached a maximum during the early stages of the flood tide and little immigration occurred during the remainder of the tide. A similar observation for $P$. plebejus in the semi-diurnal tidal region of eastern Australia has been made by Young \& Carpenter (1977). In the Norman River, however, where diurnal tides predominated, postlarvae entered the river on all flood tides, regardless of hours of darkness or light, and were distributed fairly symmetrically with tidal stages, maximum numbers occurring at the time of maximum tidal flow. Sampling at the time of maximum current velocity was, therefore, a useful measure of postlarval immigration.

Tides in the Norman River are basically of the anomolistic type with a periodicity between each spring tide phase of $27.32 \mathrm{~d}$. Synodic lunar phase changes, on the other hand, occur every $29.54 \mathrm{~d}$. It is theoretically possible to distinguish between the effects of lunar phase and tidal phase changes on postlarval immigration in this region, but because immigration was restricted to October to April each year, differences in the cycles only amounted to 9 to $10 \mathrm{~d}$ and the effects were difficult to separate. In our analyses both the rate and density of postlarvae increased at the time of spring tides, with a larger peak every second spring tide. Time series analyses suggested that this was more closely cued to tide phase signals than to lunar cycles, although on the basis of one year's data, it appeared that the spring tide near the full moon phase produced the larger peak every $27 \mathrm{~d}$. Over the $3 \mathrm{yr}$ of study, however, this interaction did not hold. Further, although the tidal range is greater every second spring tide, increased postlarval abundance was not associated with the larger tide amplitudes. During the periods of smaller tides, the time of high tide occurred at the time of moon rise and the portion of the flood tide which occurred at night would not be subjected to moonlight. As shown by Rothlisberg (1982), the degree of vertical migration of larvae offshore is largely dependent on light intensity and this in turn influences the horizontal advection. Increased dispersal could be expected during this period and may explain the increased recruitment every second spring tide.

Wind had little influence on postlarval immigration. This result is consistent with the results of Rothlisberg et al. (1983) who showed that the introduction of wind into their larval advection model had little effect on either the distance or direction of larval movement. The model also predicts that the potential for advection of larvae towards the Norman River is higher during the winter-spring months from May to November than during the summer-autumn months from December to April. Crocos \& Kerr (1983) have reported that spawning of Penaeus merguiensis in the south-eastern Gulf shows 2 peaks during the year, a small peak in October-November and a larger peak in March-April. According to the model, immigration into the Norman River, therefore, should peak in October-November each year and remain low for the remaining months. Larvae resulting from the period of intensive spawning during March and April were considered to advect away from the Norman River. The seasonal pattern of postlarvae observed during our study was variable over the four years but showed some consistencies with these predictions. Little immigration occurred during the winter months from May to September and was most consistent during the October-November period with peaks occurring during this time in 3 of the $4 \mathrm{yr}$ studied. During the autumn of 1977 (Mar), however, and again during the summer of 1977-78 (Dec, Jan, Feb), considerable postlarval immigration was observed, although the relative abundance of the autumn postlarvae compared with the spring postlarvae did not reflect the large differences in the relative abundances of autumn-spawned eggs versus springspawned eggs reported by Crocos \& Kerr (1983).

The summer period of $1977-78$ was characterized by low rainfall, and the physical barrier to postlarvae setup by the increased freshwater discharge during the wetter monsoon months did not eventuate. The pattern of immigration observed in this year with a summer maximum may reflect more closely the offshore coupling of spawning and larval dynamics. During the summer period, postlarvae were smaller and less well developed than those arriving in either spring or autumn, possibly reflecting the closer proximity of spawning adults during this time as reported by Crocos 
\& Kerr (1983). Over the 9 yr for which data on juvenile prawns have been collected in the Norman River (Hynd 1974, unpubl, and present study), a large autumn immigration of postlarvae as seen in 1977 occurred only in one other year. In both these years, spring postlarval numbers were also high, suggesting that in years of very high larval abundances, some larvae will reach the river despite unfavourable offshore current regimes. In the long term, however, the most important spawning for the species in the southeastern Gulf is the smaller spring peak which occurs in October-November.

The marked seasonality of rainfall results in physical and chemical changes associated with increased rainfall during the monsoon period being reflected in the estuary's hydrology for at least 9 mo after the wet season. Increased rainfall also produces a larger biomass of adult prawns offshore as a result of increased emigration of juvenile prawns from the estuary during the monsoon (Staples 1980b, Vance et al. in press). Some of the year-to-year variation seen in postlarval abundance could be attributed to the amount of rainfall recorded during the previous wet season. Thus, postlarval abundance was correlated with salinity, temperature and nutrient differences as well as with offshore adult prawn biomass. The causal relation between these variables remains unclear. On one hand, it could be argued that the increased postlarval abundance was a result of the increased offshore adult stock. On the other hand, increased rainfall also resulted in a lowered salinity and enrichment of the coastal waters of the Gulf and higher survival of larvae may be involved. The increased size and developmental stage of postlarvae during years of higher rainfall supports the latter idea that following good rainfall, better conditions for larval advection exist.

The importance of the phytoplankton food supply for the survival of several species of fish larvae has been well documented (e.g. Lasker 1975, 1978) and more work on the factors affecting the survival and advection of penaeid prawn larvae is needed to determine more precisely what causes the year-to-year differences seen in the strength of postlarval immigration into the estuarine nursery areas of the Gulf of Carpentaria.

Acknowledgements. The authors thank all those who assisted in this study. Special thanks are extended to D. Heales of the CSIRO Division of Fisheries Research and P. Kerr of Brisbane who assisted in much of the collection and sorting of plankton samples. J. Kerr of the CSIRO Division of Mathematics and Statistics assisted with the statistical analyses. Drs Rothlisberg. Hill and Dall, of the CSIRO Division of Fisheries Research, made valuable criticisms of the first manuscript.

\section{IITERATURE CITED}

Barrett, B. B., Gillespie, M. C. (1973). Primary factors which influence commercial shrimp production in coastal Louisiana. Wildl. Fish. Comm. Tech. Bull. 9: 1-28

Barrett, B. B., Gillespie, M. C. (1975). 1975 environmental conditions relative to shrimp production in coastal Louisiana. Wildl. Fish. Comm. Tech. Bull. 15: 1-22

Chatfield, C. (1975). The analysis of time series: theory and practice. John Wiley and Sons, New York

Chong, Ving Ching (1979). The biology of the white prawn Penaeus merguiensis de Man (Crustacea: Penaeidae) in the Pulau Angsa - Klang Strait Waters (Straits of Malacca). M. Sc. thesis, University of Malaysia, Kuala Lumpa

Crocos, P. J., Kerr, J. D. (1983). Maturation and spawning of the banana prawn Penaeus merguiensis de Man (Crustacea: Penaeidae) in the Gulf of Carpentaria, Australia. J. exp. mar. Biol. Ecol. 69: 37-59

Draper, N. R., Smith, N. (1966). Applied regression analyses. Wiley, New York

Edwards, R. R. C. (1978). The fishery and fisheries biology of penaeid shrimp on the Pacific coast of Mexico. Oceanogr. mar. Biol. A. Rev. 16; 145-180

Forbes, A. M. G., Church, J. A. (1983). Circulation in the Gulf of Carpentaria. II. Residual currents and mean sea level. Aust. J. mar. Freshwat. Res, 34: 11-22

Garcia, S., Le Reste, L. (1981). Life cycles, dynamics, exploitation and management of coastal penaeid shrimp stocks. F.A.O. Fish. Tech. Pap. 203: 1-215

Glaister, J. P. (1978). The impact of river discharge on distribution and production of the school prawn Metapenaeus macleayi (Haswell) (Crustacea: Penaeidae) in the Clarence River. Aust. J. mar. Freshwat. Res. 29: $311-323$

Goswami, S. C., George, M. J. (1978). Diel variations in occurrence of penaeid Iarvae in estuarine and nearshore waters of Goa. Indian J. mar. Sci. 7: 33-38

Gunter, G., Edwards, J. C. (1969). The relation of rainfall and fresh-water drainage to the production of the penaeid shrimps (Penaeus fluviatilis Say and Penaeus aztecus Ives) in Texas and Louisiana waters. F.A.O. Fish. Rep. 57: 875-892

Hildebrand, H. H., Gunter, G. (1953). Correlation of rainfall with the Texas catch of white shrimp, Penaeus setiferus (Linnaeus). Trans. Am. Fish. Soc. 82: 151-155

Hughes, D. A. (1969). Responses to salinity change as a tidal transport mechanism of pink shrimp Penaeus duorarum. Biol. Bull. mar. biol. Lab., Woods Hole 136: 45-53

Hunt, J. H., Carroll, R. J., Chinchilli, V., Frankenberg, D. (1980). Relationship between environmental factors and brown shrimp production in Pamlico Sound, North Carolina. Spec. Scient. Rep. No. 33, North Carolina Dept. of Natural Resources and Community Development

Hynd, J. S. (1974). Year-round prawn fishery possible in the Gulf? Aust. Fish. 33 (5): 2-5

Lasker, R. (1975). Field criteria for survival of anchovy larvae the relationship between inshore chlorophyll maximum layers and successful first feeding. Fish. Bull. U.S. 73: $453-462$

Lasker, R. (1978). The relation between oceanic conditions and larval anchovy food in the California Current: Identification factors contributing to recruitment failure. Rapp P.-v. Réun. Cons. int. Explor. Mer 173: 212-230

Motoh, H. (1981). Studies on the fisheries biology of the giant tiger prawn, Penaeus monodon in the Philippines SEAFDEC Tech. Rep. 7: 1-128 
Quinn, W. H., Neal, V. T. (1983). Long-term variations in the Southern oscillation, El Niño, and Chilean sub tropical rainfall. Fish. Bull. U.S. 81: 363-374

Rothlisberg, P. C. (1982). Vertical migration and its effect on dispersal of penaeid shrimp larvae in the Gulf of Carpentaria, Australia. Fish, Bull. U.S. 80: 541-554

Rothlisberg, P. C., Church, J. A., Forbes, A. M. G. (1983) Advection modelling of vertically migrating shrimp larvae. J. mar. Res. 41: 511-538

Rothschild, B. J., Brunenmeister, S. L. (1984). The dynamics and management of shrimp in the northern Gulf of Mexico. In: Gulland, J. A., Rothschild, B. J. (ed.) Penaeid shrimps: their biology and management. Fishing News Books Ltd., Farnham, p. 145-172

Ruello, N. V. (1973). The influence of rainfall on the distribution and abundance of the school prawn Metapenaeus macleayi in the Hunter River region (Australia). Mar. Biol. 23: $221-228$

Selvakumar, R. A., George, M. J., Achuthankutty, C. T., Goswami, S. C. (1977). Penaeid prawn larval abundance in the Mandovi Estuary, Goa. Indian J. mar. Sci. 6: 160-162

Silas, E. G., George, M. J., Jacob, T. (1984). A review of the shrimp fisheries of India: a scientific basis for the management of the resources. In: Gulland, J. A., Rothschild, B. J. (ed.) Penaeid shrimps: their biology and management. Fishing Book News Ltd., Farnham, p. 83-103

Somers, I. F., Taylor, B. R. (1981). Fishery statistics relating to the declared management zone of the Australian northern prawn fishery, 1968-1979. CSIRO Mar. Labs Rep. 138: $1-24$

Staples, D. J. (1979). Seasonal migration patterns of postlarval and juvenile banana prawns, Penaeus merguiensis de Man, in the major rivers of the Gulf of Carpentaria, Australia. Aust. J. mar. Freshwat. Res. 30: 143-157

Staples, D. J. (1980a). Ecology of juvenile and adolescent banana prawns, Penaeus merguiensis, in a mangrove estuary and adjacent off-shore area of the Gulf of Carpentaria. I. Immigration and settlement of postlarvae. Aust. J. mar. Freshwat. Res. 31: 635-652
Staples, D. J. (1980b). Ecology of juvenile and adolescent banana prawns, Penaeus merguiensis, in a mangrove estuary and adjacent off-shore area of the Gulf of Carpentaria. II. Emigration, population structure and growth of juveniles. Aust. J. mar. Freshwat. Res. 31: 653-665

Staples, D. J. (1983). Environmental monitoring: climate of Karumba and hydrology of the Norman River estuary. south-east Gulf of Carpentaria. CSIRO Mar. Labs Rep. 156: $1-11$

Staples, D. J., Vance, D. J. (1979). Effects of changes in catchability on sampling of juvenile and adolescent banana prawns, Penaeus merguiensis de Man. Aust. J. mar. Freshwat. Res. 30: 511-519

Subrahmanyam, M. (1966). Fluctuations in prawn landings in the Godavari estuarine system. Proc. Indo-Pacific Fish. Counc. 11 (2): 44-51

Thomson, J. M. (1955). Fluctuations in Australian prawn catch. Proc. Indo-Pacif. Fish. Coun. 6th Sess. (III) : 444-447

Vance, D. J., Staples, D. J., Kerr, J. D. (in press). Factors affecting the year-to-year variation in the catch of banana prawns, Penaeus merguiensis, in the Gulf of Carpentaria, Australia. J. Cons. int. Explor. Mer

Van Zalinge, N. P. (1984). The shrimp fisheries in the Gulf between Iran and the Arabian Peninsula. In: Gulland, J. A., Rothschild, B. J. (ed.) Penaeid shrimps: their biology and management. Fishing Book News Ltd., Farnham, p. $71-82$

Williams, A. B. (1969). Penaeid shrimp catch and heat summation, an apparent relationship. F.A.O. Fish. Rep. 57 (3) 643-656

Winer, B. J. (1971). Statistical principles in experimental design 2nd ed. McGraw-Hill Kogasha, Tokyo

Underwood, A. J. (1981). Techniques of analysis of variance in experimental marine biology and ecology. Oceanogr. mar. Biol. A. Rev. 19: 513-605

Young, P. C., Carpenter, S. M. (1977). Recruitment of postlarval penaeid prawns to nursery areas in Moreton Bay, Queensland. Aust. J. mar. Freshwat. Res. 28: 745-773 